\title{
Assessment of Consumer Participation and Behaviour towards the "No Plastic Bag Campaign" in Kuala Lumpur
}

\section{Sharifah Norkhadijah Syed Ismail, Nur Syakirah Hanani Binti Suhaimi,} Karmegam Karuppiah

To Link this Article: http://dx.doi.org/10.6007/IJARBSS/v11-i19/11717

DOI:10.6007/IJARBSS/v11-i19/11717

Received: 10 October 2021, Revised: 12 November 2021, Accepted: 28 November 2021

Published Online: 15 December 2021

In-Text Citation: (Ismail et al., 2021)

To Cite this Article: Ismail, S. N. S., Suhaimi, N. S. H. B., \& Karuppiah, K. (2021). Assessment of Consumer Participation and Behaviour towards the "No Plastic Bag Campaign" in Kuala Lumpur. International Journal of Academic Research in Business and Social Science, 11(19), 68-80.

\section{Copyright: (C) 2021 The Author(s)}

Published by Human Resource Management Academic Research Society (www.hrmars.com) This article is published under the Creative Commons Attribution (CC BY 4.0) license. Anyone may reproduce, distribute, translate and create derivative works of this article (for both commercial and non-commercial purposes), subject to full attribution to the original publication and authors. The full terms of this license may be seen

at: http://creativecommons.org/licences/by/4.0/legalcode

Special Issue Title: Youth and Community Wellness, 2021, Pg. 68 - 80

Full Terms \& Conditions of access and use can be found at http://hrmars.com/index.php/pages/detail/publication-ethics 


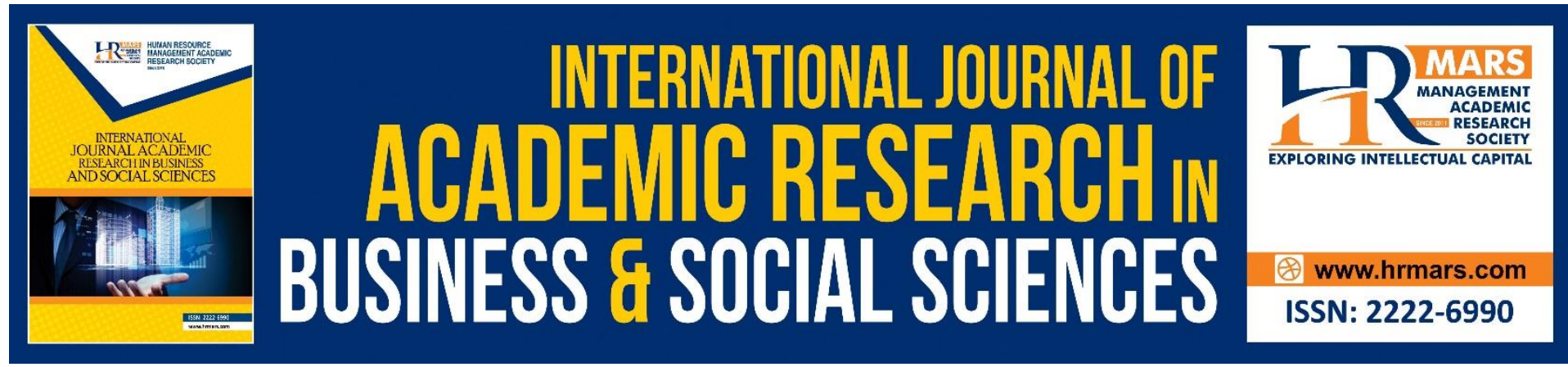

\title{
Assessment of Consumer Participation and Behaviour towards the "No Plastic Bag Campaign" in Kuala Lumpur
}

\author{
Sharifah Norkhadijah Syed Ismail ${ }^{1,2}$, Nur Syakirah Hanani Binti \\ Suhaimi ${ }^{2}$, Karmegam Karuppiah² \\ ${ }^{1}$ Institute for Social Science Studies, Universiti Putra Malaysia, 43400 UPM Serdang, \\ Selangor, Malaysia, ${ }^{2}$ Department of Environmental and Occupational Health, Faculty of \\ Medicine and Health Science, University Putra Malaysia, Selangor, Malaysia.
}

Corresponding Author Email: norkhadijah@upm.edu.my

\begin{abstract}
This study assessed the consumer's participation and behavior in the plastic bag campaign in the country. Participant observation and assessment were conducted among 396 shoppers at 3 different stores (i.e. hypermarket, supermarket, and convenience store) around Kuala Lumpur. Half of the shoppers in this study were observed purchased plastic bags $(52 \%, n=$ 206) while shopping. They are mainly the supermarket (66.7\%) and hypermarket visitors (54.5\%). Meanwhile, $48 \%(n=190)$ of shoppers did not purchase plastic bags and mainly the visitors of the convenience store (52.3\%). Most of the male shoppers purchase plastic bags while shopping $(55.2 \%, 96$ out of 174$)$. Only $49.5 \%$ of female shoppers $(n=110)$ purchase plastic bags. This study also highlights $63.9 \%$ of the consumers who shopped in a group usually pay for plastic bags. High participation was observed among visitors of the convenience store ( $N=86,65.2 \%)$ and those who shopped alone ( $N=151,52.4 \%)$. There is a significant association between shoppers' participation in the "no plastic bag campaign" with the type of retailers $\left(X^{2}=38.075, p=<0.001\right)$ and shopped alone $\left(X^{2}=0.177, p=<0.001\right)$. Participation in the campaign was not associated with gender, ethnicity, time, and week of shopping. In conclusion, the observation of consumer behaviors and participation in the plastic bag campaign was considered as low and need for further encouragement.
\end{abstract}

Keywords: Plastic Bag, Environmental Campaign, Human Behaviors, Shoppers, Retailers

\section{Introduction}

Plastic bags have been introduced in the 1970s and widely used among households, retailers and consumers since then (Chitotombe, 2014). It was estimated around 500 billion plastic bags are used every year worldwide (Adane \& Muleta, 2011). According to Jambeck and his associates in 2015, Malaysia is ranking eighth out of 192 coastal countries in the world for the largest producing mismanaged plastic wastes. The study estimated that in 2010 Malaysia had produced 0.94 million metric tons (MMT/ year) of mismanaged plastic waste where 0.14 to 0.37 million metric tons may have entered the ocean as plastic marine debris. The study 
stated that thirteen percent of Malaysia's solid waste consists of plastic waste of which 57 percent of it was mismanaged waste (Jambeck, 2015). According to the Malaysian Plastics Manufacturers Association, two million tons of resins for the plastic industry were reported produced locally in Malaysia per annum (JPSPN, 2011). The statistics from 2007 to 2010 reported Selangor was recorded as the state with the highest volumes of solid waste collected which is 1.15 million tonnes followed by Kuala Lumpur (750,000 tonnes) (JPSPN, 2011).

Standard plastic bags consist of thin polyethylene (PE) sheet which is commercially produced from the polymerization of ethylene and categorized based on the density and molecular branching frequency. There are two important types in plastic bag production such as lowdensity polyethylene (LDPE) a high-density polyethylene (HDPE) (Sharma \& Rajagopalan, 2014).

A single plastic bag generates $3.0 \times 10^{-4}$ tons of carbon dioxide $\left(\mathrm{CO}_{2}\right)$ equivalently to $0.03 \mathrm{~kg}$ of $\mathrm{CO}_{2}$ (Equinox Center, 2013). Plastic bags were mainly disposed of in landfills. Landfills have contributed nearly $20 \%$ of greenhouse gases which results in global warming that leads to climate change. It was observed that $95 \%$ probability of an increase in earth temperatures over the past 50 years is because of human-produced greenhouse gases such as carbon dioxide $\left(\mathrm{CO}_{2}\right)$, methane $\left(\mathrm{CH}_{4}\right)$, and nitrous oxide $\left(\mathrm{N}_{2} \mathrm{O}\right)$ (Global Climate Change (GCC), 2018). Leaching of toxic chemicals resulting from the breakdown of plastic materials and potential of hormone level disruption in animals and then would be later consumed by humans (Ritch, Brennanand \& Macleod, 2009: Aldred, 2007).

The "No Plastic Bag Campaign Day" was launched by the Ministry of Domestic Trade, Cooperative and Consumerism (MDTCC) throughout Malaysia each Saturday since January 2011 (MDTCC, 2012) to reduce the excessive consumption of plastic bags and save the environment. The nationwide campaign involved major retailer outlets, supermarkets, and hypermarkets for every Saturday at the customer end level. The new plastic bags were allowed when carrying wet groceries and food for wet markets, restaurants, and night markets for hygiene purposes (Safitri, Rahmalan, \& Wahid, 2013). The campaign imposes a 0.20 cents (USD 0.6) charge per plastic bag for each new plastic bag requested by customers during the campaign on Saturday (Kamaruddin \& Yusuf, 2012, Asmuni, Hussin, Khalili, \& Zain, 2015). The charge on the levy was introduced to minimize the amount of plastic bags used and indirectly reduce waste disposal to the landfill and prevent littering (Thomas, Poortinga, \& Sautkina, 2016).

Research on consumer participation and behavior towards the "No plastic bag campaign" in the country was not widely explored. Public participation in environmental management brings many benefits and people are already aware of that (Lim, 2012). There is a large number has focused on recycling behavior (Asmuni, Khalili, \& Zain, 2012; Singhirunnusorn et al., 2012) and research focusing on consumer attitudes and behavior in this area is lacking. Therefore, this study was conducted to observe consumers' participation and behavior towards the "No plastic bag campaign". The findings of this study provide the extent of consumers' participation in the plastic campaign in the country and assist the related stakeholders in the improvement of the campaign.

\section{Materials and Method}

Consumers' participation and behavior towards the "No plastic bag campaign" was observed in this study from March to June 2019. The observation was conducted among shoppers at 
Sri Petaling, Kepong, and Cheras Kuala Lumpur. These are the most populated areas in Kuala Lumpur, with a mixed development comprising residential and commercial lands, educational institutions, hypermarkets, shopping complex, with over 100 retail shops and retailers (Kuala Lumpur Structure Plan 2020). Three different retailers; the hypermarket, supermarket and convenience stores were involved in this study. This allows a variety of consumers to be observed at different convenience levels and price ranges. The hypermarket is where almost all types of products can be found with a high level of convenience for shoppers as the area is large, combined supermarkets and department stores. The supermarket offers a wide variety of food and household products and is larger in size and wide selection than a convenience store but smaller and more limited compared to the hypermarket. The convenience store is a small retail business that stocks a limited range of household goods and groceries that offers more essential items and have a relatively narrower range of products compared to the supermarkets and hypermarkets. Many convenience stores operate 24 hours on a small floor area (DBS Group Research, 2015). In the UK for example, a convenience store is defined as a grocery store selling food and drink for odd-premises consumption as their main activity, with less than $3000 \mathrm{ft}^{2}$ floor area, open more than eight hours per day, seven days per week (Adams et al., 2012).

In total, 396 shoppers' behavior was observed by the researcher based on the provided checklist. Three main items were observed, namely; (1) the sociodemographic characteristic such as gender and ethnicity; (2) the store participation in the campaign such as the interaction between the cashier and the consumers about the plastic bag campaign, the readiness to pay RM0.20 cents per plastic bag and also the availability of in-store information about the campaign, and (3) the consumers' behavior such as methods of carrying goods and number of plastic bags purchased. A structured checklist form was adopted and modified from a study by Asmuni et al., (2015). The checklist was developed based on the criteria and scope of the study to identify important key behavior and that consumers' behavior. The checklist form was divided into three parts; Part A (the sociodemographic background), Part $B$ (store participation in the campaign), and Part $C$ (consumers' participation). The checklist was validated by an expert panel from the Department of environmental and occupational Health Sciences, UPM.

\section{Statistical Analysis}

Statistical analyses were performed using SPSS Statistics Version 25. The sociodemographic characteristics, store participation, and consumer behavior were summarized by descriptive analysis. Chi-square test was used to determine the association between variables with the consumers' behavior.

\section{Results and Discussion \\ Socio-demographic Background}

There is a significant difference in the gender of shoppers observed where females are the majority of them $(n=222,56.1 \%)$. They are mainly shopped in the supermarket $(40.1 \%)$ and hypermarket $(38.7 \%)$ whereas the male shoppers were mainly shopped at the convenience store $(48.9 \%)$ (Table 1$)$. There is a significant difference of retailers visited by the ethnicity where Malay (33.9\%) and Chinese (41.0\%) were mostly shopping in supermarkets while most Indians $(40.8 \%)$ shop at the convenience store. The shopping condition also showed a significant difference by type of retailers where a majority of the shoppers in a group visited hypermarkets $(56.5 \%)$ whereas shoppers visited the convenience store $(39.2 \%)$ shop alone. 
This is probably due to the size of the hypermarket and the variety of products that make it is convenient for group shopping. There is no significant trend in the time of shopping by retailers. Most shoppers visited the supermarket and convenience store (33.8\%) from 10.00 am to $1.00 \mathrm{pm}$ while the hypermarket between $2.00 \mathrm{pm}$ to $5.00 \mathrm{pm}(33.8 \%)$ and $6.00 \mathrm{pm}$ to $10.00 \mathrm{pm}(33.9 \%)$ in the evening. There is also no obvious trend in the time shopping of the month.

Different consumers may have different ways of shopping. Middle-aged people from middle income to high income prefer to shop at large retail stores for greater product and service variety (Arnold, Luthra, \& Arnold, 2006). Rising affluence, education level, and mass media have made the consumers more sophisticated, affluent, and cosmopolitan. Large-scale retail outlets such as hypermarkets and supermarkets were often to be visited by the majority of Malaysians such as the youngsters with private cars as the main mode of transportation (Mui \& Ghafar, 2003). Malaysian youngsters prefer shopping for various occasions such as meeting up with friends, for exploration, and as a convenient place to obtain a variety of services and products under one roof (Hassan et al., 2015). The aesthetic interior design with music, decoration, and lighting could be an attraction for young customers and would be an opportunity for the hypermarket's management (Ahmed et al., 2013). 
INTERNATIONAL JOURNAL OF ACADEMIC RESEARCH IN BUSINESS AND SOCIAL SCIENCES

Vol. 11, No. 19, Youth and Community Wellness, 2021, E-ISSN: 2222-6990 @ 2021 HRMARS

Table 1: Sociodemographic of respondents observed

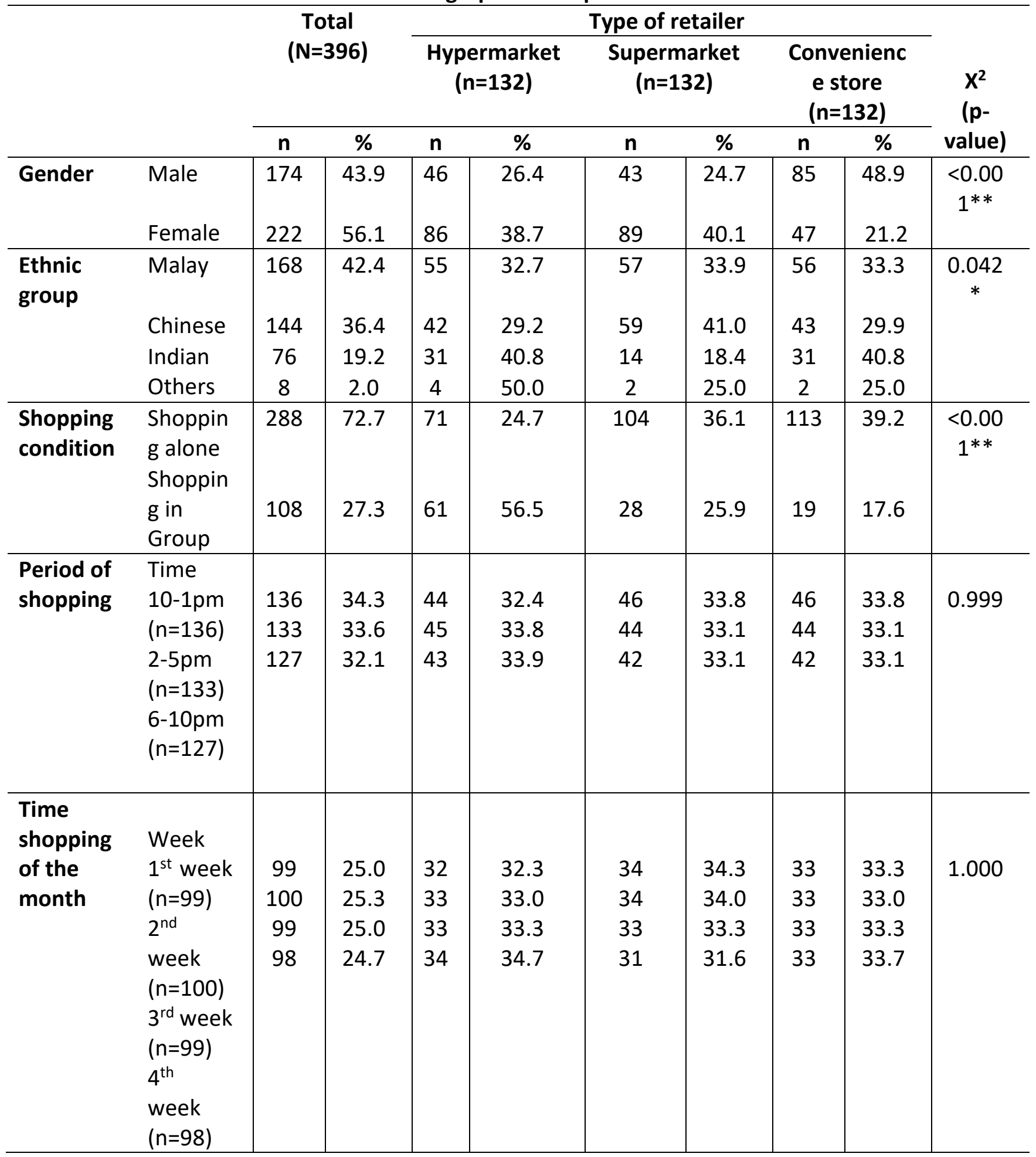

Note: (\%) percentage row 


\section{Shoppers Behavior on the Plastic Bag Usage}

Half of the shoppers in this study were observed purchased plastic bags $(52 \%, n=206)$ while shopping. They are mainly the supermarket (66.7\%) and hypermarket visitors $(54.5 \%)$. Meanwhile, $48 \%(n=190)$ of shoppers are mainly in the convenience store $(52.3 \%)$ did not purchase plastic bags. Other methods used by the shoppers to carry their belonging are by hand or with the help of a trolley, bringing their shopping bags, and buying an eco-friendly bag from the store. Some of them used both plastic and eco-friendly bag to carry their items. The usage of plastic bags is possibly influenced by the type of retailers. Shoppers in large retailers such as in the hypermarket and supermarket, tend to buy more and variety of goods and sometimes the shopping bags they have not adequate for the number of items they purchased. This makes them need to purchase more plastic bags. In contrast, the convenience store is much smaller where buyers have limitations to choose the product and goods and end up purchasing only on necessary needs where no or fewer plastic bags are needed.

Furthermore, consumers' buying behavior was influenced by their needs and preferences. The geographic distribution of one's homes and how far do they travel to the store was one of the reasons to influence customer buying behavior patterns. This was concerning the place of purchase of selecting store locations, in choosing distributors for a product, and in merchandising. Consumers usually prefer to go to large retail stores for major purchases to get a better price, special offers, better assortments, meanwhile, they prefer the smaller retail stores for minor refill trips (Reutterer \& Teller, 2009).

Most of the male shoppers purchase plastic bags while shopping (55.2\%, 96 out of 174). Only $49.5 \%$ of female shoppers or 110 out of 222 purchase plastic bags. Besides, $18.0 \%$ of the observed female brought their shopping or recycle while only $9.2 \%$ of male shoppers did the same. This is possibly due to the participation in environmental actions campaign was viewed as more feminine. Therefore, this has caused male shoppers to prefer single-use plastic more compared to reusable or recyclable shopping bags (Brough, 2016).

This study also highlights $63.9 \%$ of the consumers who shopped in a group usually pay for plastic bags rather than bringing their shopping bag (18.5\%). Only $2.8 \%$ of them used the trolley, $6.5 \%$ use both plastics and recyclable bag (6.5\%) and the least was to buy an ecofriendly bag from the store (1.9\%).

This study also observed that majority of the retail visitors at 2 to $5 \mathrm{pm}$ purchased plastic bags (60.9\%). This is possibly influenced by the time allocation for shopping that encourages their satisfaction (Geiger, 2007) and enjoyment (Shannon \& Mandhachitara, 2008) that encourage the usage of plastic bags more conveniently. In contrast, the period of shopping by a week of the month did not show an obvious trend on plastic bag purchased as the percentage remains quite the same. However, this variable has been reported in several studies as one of the indications that influence the time shoppers spent in the retailers. People mostly spend time went shopping for household necessities for around 20 to 30 minutes per day or 3.5 to 5 hours per week. The time of purchase patterns was related to the weather, seasons, and regional differences. Most shoppers were found to prefer to go shopping over the weekend, hence hypermarkets become more crowded during that time (Hassan et al., 2015). 
INTERNATIONAL JOURNAL OF ACADEMIC RESEARCH IN BUSINESS AND SOCIAL SCIENCES

Vol. 11, No. 19, Youth and Community Wellness, 2021, E-ISSN: 2222-6990 @ 2021 HRMARS

Table 2: The descriptive summary of consumers' behavior on plastic bag usage ( $N=396)$

\begin{tabular}{|c|c|c|c|c|c|c|c|c|c|c|c|c|c|}
\hline \multirow{2}{*}{\multicolumn{2}{|c|}{ Variables }} & \multicolumn{2}{|c|}{$\begin{array}{l}\text { Pay for } \\
\text { plastic } \\
(n=206)\end{array}$} & \multicolumn{2}{|c|}{$\begin{array}{c}\text { Brings } \\
\text { own } \\
\text { shopping } \\
\text { bag } \\
(n=56)\end{array}$} & \multicolumn{2}{|c|}{$\begin{array}{c}\text { Buy eco } \\
\text { bag } \\
(n=13)\end{array}$} & \multicolumn{2}{|c|}{$\begin{array}{l}\text { Use both } \\
\text { plastic } \\
\text { and eco } \\
\text { bag } \\
(n=13)\end{array}$} & \multicolumn{2}{|c|}{$\begin{array}{c}\text { Carry } \\
\text { items by } \\
\text { hand } \\
(n=92)\end{array}$} & \multicolumn{2}{|c|}{$\begin{array}{c}\text { Use } \\
\text { trolley } \\
(n=16)\end{array}$} \\
\hline & & $\mathbf{N}$ & $(\%)$ & $\mathrm{n}$ & $(\%)$ & $n$ & (\%) & $n$ & (\%) & $n$ & (\%) & $n$ & (\%) \\
\hline \multirow[t]{3}{*}{$\begin{array}{l}\text { Type of } \\
\text { retailer }\end{array}$} & $\begin{array}{l}\text { Hypermarket } \\
(n=132)\end{array}$ & 72 & 54.5 & 30 & 22.7 & 5 & 3.8 & 7 & 5.3 & 9 & 6.8 & 9 & 6.8 \\
\hline & $\begin{array}{l}\text { Supermarket } \\
(n=132)\end{array}$ & 88 & 66.7 & 10 & 7.6 & 8 & 6.1 & 6 & 4.5 & 14 & 10.6 & 6 & 4.5 \\
\hline & $\begin{array}{l}\text { Convenience } \\
\text { store }(n=132)\end{array}$ & 46 & 34.8 & 16 & 12.1 & 0 & 0.0 & 0 & 0.0 & 69 & 52.3 & 1 & 0.8 \\
\hline \multirow[t]{2}{*}{ Gender } & Male (n=174) & 96 & 55.2 & 16 & 9.2 & 0 & 0.0 & 1 & 0.6 & 56 & 32.2 & 11 & 5.0 \\
\hline & $\begin{array}{l}\text { Female } \\
(n=222)\end{array}$ & 110 & 49.5 & 40 & 18.0 & 13 & 5.9 & 12 & 5.4 & 36 & 16.2 & 16 & 4.0 \\
\hline \multirow[t]{4}{*}{ Race } & Malay $(n=168)$ & 95 & 56.5 & 21 & 12.5 & 4 & 2.4 & 6 & 3.6 & 39 & 23.2 & 3 & 1.8 \\
\hline & $\begin{array}{l}\text { Chinese } \\
(n=144)\end{array}$ & 77 & 53.5 & 19 & 13.2 & 6 & 4.2 & 3 & 2.1 & 32 & 22.2 & 7 & 4.9 \\
\hline & Indian $(n=76)$ & 31 & 40.8 & 13 & 17.1 & 3 & 3.9 & 3 & 3.9 & 21 & 27.6 & 5 & 6.6 \\
\hline & Others $(n=8)$ & 3 & 37.5 & 3 & 37.5 & 0 & 0.0 & 1 & 12.5 & 0 & 0.0 & 1 & 12.5 \\
\hline \multirow[t]{2}{*}{$\begin{array}{l}\text { Shop } \\
\text { behaviour }\end{array}$} & $\begin{array}{l}\text { Shop alone } \\
(n=288)\end{array}$ & 137 & 47.6 & 36 & 12.5 & 11 & 3.8 & 6 & 2.1 & 85 & 29.5 & 13 & 4.5 \\
\hline & $\begin{array}{l}\text { Shop in a } \\
\text { group }(n=108)\end{array}$ & 69 & 63.9 & 20 & 18.5 & 2 & 1.9 & 7 & 6.5 & 7 & 6.5 & 3 & 2.8 \\
\hline \multirow[t]{3}{*}{$\begin{array}{l}\text { Period of } \\
\text { shopping } \\
\text { (Time) }\end{array}$} & $\begin{array}{l}10-1 p m \\
(n=136)\end{array}$ & 68 & 50.0 & 20 & 14.7 & 4 & 2.9 & 4 & 2.9 & 35 & 25.7 & 5 & 3.7 \\
\hline & $\begin{array}{l}2-5 \mathrm{pm} \\
(\mathrm{n}=133)\end{array}$ & 81 & 60.9 & 14 & 10.5 & 1 & 0.8 & 3 & 2.3 & 30 & 22.6 & 4 & 3.0 \\
\hline & $\begin{array}{l}\text { 6-10pm } \\
(\mathrm{n}=127)\end{array}$ & 57 & 44.9 & 22 & 17.3 & 8 & 6.3 & 6 & 4.7 & 27 & 21.3 & 7 & 5.5 \\
\hline \multirow{4}{*}{$\begin{array}{l}\text { Period of } \\
\text { shopping } \\
\text { (Week) }\end{array}$} & $\begin{array}{ll}1^{\text {st }} & \text { week } \\
(n=99) & \\
\end{array}$ & 52 & 52.5 & 9 & 9.1 & 2 & 2.0 & 1 & 1.0 & 31 & 31.3 & 4 & 4.0 \\
\hline & $\begin{array}{l}2^{\text {nd }} \text { week } \\
(n=100)\end{array}$ & 55 & 55.0 & 17 & 17.0 & 3 & 3.0 & 5 & 5.0 & 18 & 18.0 & 2 & 2.0 \\
\hline & $\begin{array}{ll}3^{\text {rd }} & \text { week } \\
(n=99) & \end{array}$ & 53 & 53.5 & 15 & 15.2 & 4 & 4.0 & 5 & 5.1 & 18 & 18.2 & 4 & 4.0 \\
\hline & $\begin{array}{l}4^{\text {th }} \quad \text { week } \\
(n=98)\end{array}$ & 46 & 46.9 & 15 & 15.3 & 4 & 4.1 & 2 & 2.0 & 25 & 25.5 & 6 & 6.1 \\
\hline
\end{tabular}

Note: (\%) row percentage 
The Association between Variables with the Shoppers' Participation in the "No Plastic Bag Campaign"

There is a significant association between shoppers' participation in the "no plastic bag campaign" with the type of retailers $\left(X^{2}=38.075, p=<0.001\right)$ and whether they shopped alone or in a group $\left(X^{2}=0.177, p=<0.001\right)$. High participation was observed among visitors of the convenience store $(N=86,65.2 \%)$ and those who shopped alone ( $N=151,52.4 \%)$ (Table 3$)$. High participation in the plastic bag campaign among visitors of the convenience store perhaps due to the nature that this retailer is much smaller with a limited choice of products and shoppers only purchase the essential items where no or fewer plastic bags are needed. Even though there are supermarkets that offer alternative reusable shopping bags, provide information on environmental damage associated with plastic bag usage, and also encourage consumers to pack as many groceries in one bag to discourage shoppers from purchasing plastic bags (Cherrier, 2006) but this does not encourage shoppers participation in this study ( $N=44,33.3 \%$ ). Good participation among shoppers who shopped alone as it was observed they mainly bought fewer items compared to shoppers in a group.

Our findings highlight the participation in the campaign was not associated with gender $\left(X^{2}=0.012, p=0.496\right)$, race $\left(X^{2}=5.104, p=0.164\right)$, and time of shopping $\left(X^{2}=3.552, p=0.169\right)$, and week of shopping $\left(X^{2}=1.956, p=0.582\right)$. 
Table 3: Association between shoppers' participation in the plastic bag campaign with the types of retailer, the socio-demographic, shopping period.

Note: \%= Row percentage, *p-value $<0.05$ is statistically significant, Chi-square test.

\begin{tabular}{|c|c|c|c|c|c|}
\hline Variables & & $\begin{array}{l}\text { Participate in } \\
\text { the campaign } \\
(n=190)\end{array}$ & $\begin{array}{l}\text { Not participate in } \\
\text { the campaign } \\
(n=206)\end{array}$ & $x^{2}$ & p-value \\
\hline \multirow{3}{*}{$\begin{array}{l}\text { Type of } \\
\text { retailers }\end{array}$} & Hypermarket (132) & $60(45.5)$ & $72(54.5)$ & 38.075 & $<0.001^{*}$ \\
\hline & Supermarket (132) & $44(33.3)$ & $88(66.7)$ & & \\
\hline & $\begin{array}{l}\text { Convenience store } \\
\text { (132) }\end{array}$ & $86(65.2)$ & $46(34.8)$ & & \\
\hline \multirow[t]{2}{*}{ Gender } & Male (174) & $77(44.8)$ & $96(55.2)$ & 0.012 & 0.496 \\
\hline & Female (222) & $112(50.5)$ & $110(49.5)$ & & \\
\hline \multirow{4}{*}{$\begin{array}{l}\text { Ethnic } \\
\text { group }\end{array}$} & Malay (168) & $73(43.5)$ & $95(56.5)$ & 5.104 & 0.164 \\
\hline & Chinese (144) & $67(46.5)$ & $77(53.5)$ & & \\
\hline & Indian (76) & $45(59.2)$ & $31(40.8)$ & & \\
\hline & Others (8) & $5(62.5)$ & $3(37.5)$ & & \\
\hline \multirow{2}{*}{$\begin{array}{l}\text { Shop } \\
\text { behaviour }\end{array}$} & Shop alone (288) & $151(52.4)$ & $137(47.6)$ & 12.345 & $<0.001^{*}$ \\
\hline & Shop in a group (108) & $39(36.2)$ & $69(63.8)$ & & \\
\hline \multirow{9}{*}{$\begin{array}{l}\text { Period of } \\
\text { shopping }\end{array}$} & Time & & & & \\
\hline & 10-1pm (136) & $68(50.0)$ & $68(50.0)$ & 3.552 & 0.169 \\
\hline & $2-5 p m(133)$ & $52(39.1)$ & $81(60.9)$ & & \\
\hline & 6-10pm (127) & $70(55.1)$ & $57(44.9)$ & & \\
\hline & Week & & & & \\
\hline & $1^{\text {st }}$ week (99) & $47(47.5)$ & $52(52.5)$ & 1.956 & 0.582 \\
\hline & $2^{\text {nd }}$ week (100) & $45(45.0)$ & $55(55.0)$ & & \\
\hline & $3^{\text {rd }}$ week (99) & $46(46.5)$ & $53(53.5)$ & & \\
\hline & $4^{\text {th }}$ week $(n=98)$ & $52(53.1)$ & $46(46.9)$ & & \\
\hline
\end{tabular}

\section{Stores Participation in the Plastic Bag Campaign}

Throughout the observation among cashiers in all three stores, all of them did ask the customers whether they wanted plastic bags or not. In hypermarket and convenience stores, cashiers have informed the customers that no plastic bag was given and they need to pay 0.20 cents for every purchase while the supermarket cashiers usually do not remind customers about the purchasing and the charge. In-store information was observed to be available in all three types of retailers (i.e. hypermarket, supermarket, and convenience store). A study based in Mangalore city India observed that $82.4 \%$ of the shop keepers handed them plastic bags after they purchased without even asking them if they required more bags for carrying goods (Joseph et al., 2016). It was reported that one of the leading causes that result on the environmentally unfriendly practices in developing countries was poor awareness among people and the public (Gupta \&Somanathan, 2014). Generation initiatives for various means of easy availability of information should be supported. The 
display banners of the use of alternative bags in the store could be an effective information strategy for creating awareness, the pamphlets on the effects and hazards of plastic bags need to be put near the check-outs or cash counters (Joseph et al., 2016).

\section{Conclusion}

In conclusion, the observation of consumers' participation in the plastic bag campaign in the study area was considered as low. It was observed a high number of plastic bags were purchased despite the charge on the plastic bags. All of the observed stores participate in the campaign through the interaction made with the customer about the plastic campaign and there was in-store information such as posters and banners available in each store. High participation in the campaign was observed among visitors to the convenience store and those who shopped alone. Most of the male shoppers purchase plastic bags while shopping and female shoppers mainly brought their shopping or recycle bag. Shoppers in a group usually pay for plastic bags rather than bringing their shopping bags. The majority of the retail visitors at 2 to 5 pm purchased plastic bags. A significant association between shoppers' participation with the type of retailers and shopped alone.

\section{Acknowledgment}

The author gratefully acknowledged the support provided by the staff of the Department of Environmental and Occupational Health, University Putra Malaysia (UPM) involved during the completion of this study.

\section{Reference}

Abhigyan. (2019). Use of plastic bags: factors affecting ecologically oriented behaviour in consumers [Internet]. Delhi: Foundation for Organisational Research and Education; 2008 Oct-Dec. Available from: http://www.freepatentsonline.com/article/Abhigyan/192438179.html.

Adane, L., \& Muleta, D. (2011). Survey on the usage of plastic bags, their disposal and adverse impacts on environment: A case study in Jimma City, Southwestern Ethiopia, 3, 234-248.

Ahmed, Z. U., Ghingold, M., Dahari, Z., Ahmed, Z. U., \& Ghingold, M. (2013). Malaysian shopping mall behavior : an exploratory study. https://doi.org/10.1108/13555850710827841

Applebaum, W. (1932). Studying Customer Behavior In, 172-179.

Arnold, S. J., Luthra, M. N., \& Arnold, S. J. (2006). Market entry effects of large format retailers : a stakeholder analysis.

Article, O., \& Ltdoxford, B. P. (2006). Consumer identity and moral obligations in non-plastic bag consumption : a dialectical perspective, 515-523.

Asmuni, S., Hussin, N. B., Khalili, J. M., \& Zain, Z. M. (2015). Asia Pacific International Conference on Environment-Behaviour Studies Public Participation and Effectiveness of the No Plastic Bag Day Program in Malaysia. Procedia - Social and Behavioral Sciences, 168, 328-340. https://doi.org/10.1016/j.sbspro.2014.10.238

Bierwirth, P. N. (2016). Carbon dioxide toxicity and climate change: a serious unapprehended risk for human health ., 1-17. 
https://doi.org/10.13140/RG.2.1.3297.9368

Chitotombe, J. W. (2014). The plastic bag ' ban ' controversy in Zimbabwe : An analysis of policy issues and local responses, 3(5), 1000-1012.

Communication, S., Joseph, N., Kumar, A., Majgi, S. M., Kumar, G. S., Babu, R., \& Prahalad, Y. (2016). Usage of Plastic Bags and Health Hazards : A Study to Assess Awareness Level and Perception about Legislation Among a Small Population of Mangalore City, 1-4. https://doi.org/10.7860/JCDR/2016/16245.7529

Consumer identity and moral obligations in non-plastic bag consumption: A dialectical Perspective. International Journal of Consumer Studies, 30 (5), 515-523. doi:10.1111/j.1470-6431.2006.00531.x

Gupta, K., Somanathan, R. (2011). Consumer response to incentives to reduce plastic bag use: Evidence from a field experiment in urban India [Internet]. Delhi: Delhi School of Economics; Available from:

http://www.isid.ac.in/ pu/conference/dec_11_conf/Papers/KanupriyaGupta.pdf.

Hassan, H., Rahman, M. S., \& Sade, A. B. (2015). Shopping Day and Time Preferences of Malaysian Hypermarket Consumers Shopping Day And Time Preferences of Malaysian.

Jakovcevic, A., Steg, L., Mazzeo, N., Caballero, R., \& Franco, P. (2014). Charges for plastic bags: Motivational and behavioral effects. Journal of Environmental Psychology, 40, 372-380. https://doi.org/10.1016/j.jenvp.2014.09.004

Jambeck, J. R. (2015). The Ocean. Climate Change 2014: Impacts, Adaptation and Vulnerability, 347, 1655-1732. https://doi.org/10.1017/СВ09781107415386.010

JPSPN. (2011). A Study On Plastic Management In Peninsular Malaysia National Solid Waste Management Department Ministry Of Housing And Local Government Malaysia -Final Report.

Kamaruddin, R., \& Yusuf, M. (2012). Selangor Government's “ No plastic Bag Day” Campaign: Motivation and Acceptance Level, 42(July 2010), 205-211. https://doi.org/10.1016/j.sbspro.2012.04.183

Lynn, H., Rech, S., \& Gabizon, S. (2016). Plastics, Gender and the Environment Life cycle of plastics and its impacts on wo men and men.

Ministry of Domestic Trade,Cooperatives and Consumerism (MDTCC), (2012).

Available from:

http://www.kpdnkk.gov.my/web/guest/media-majlis-pelancaran kempenkurangkanpenggunaan-beg-plastik-dan-hari-tanpa-beg-plastik.

Musa, H. M., Hayes, C., Bradley, M. J., Clayson, A., \& Gillibrand, G. (2016). Measures Aimed at Reducing Plastic Carrier Bag Use: A Consumer Behaviour Measures Aimed at Reducing Plastic Carrier Bag Use : A Consumer Behaviour Focused Study. https://doi.org/10.12966/ne.06.02.2013

Nagra, V. (2010). Environmental education awareness among school teachers, 153-162. https://doi.org/10.1007/s10669-010-9257-x

Poortinga, W., Whitmarsh, L., \& Suffolk, C. (2013). The introduction of a single-use carrier bag charge in Wales: Attitude change and behavioural spillover effects. Journal of Environmental Psychology, 36, 240-247. https://doi.org/10.1016/j.jenvp.2013.09.001

Reutterer, T., Teller, C., \& Reutterer, T. (2009). Store format choice and shopping trip types. https://doi.org/10.1108/09590550910966196 
Ruban, A., Gloria, S., \& Fernandez, L. G. (2012). Plastic Bag Production Life Cycle Assessment of Plastic Bag Production Life Cycle Assessment of Plastic Bag Production Anna Ruban.

Sa, N., \& Ss, Q. (n.d.). Is Global Warming likely to cause an increased incidence of Malaria, 18-22. https://doi.org/10.4176/090105

Safitri, I., Rahmalan, Z., \& Wahid, A. (2013). No plastic bag campaign day in Malaysia and the policy implication, 1259-1269. https://doi.org/10.1007/s10668-013-9437-1

Shannon, R., \& Mandhachitara, R. (2008). Causal path modeling of grocery shopping in hypermarkets. https://doi.org/10.1108/10610420810896086

Spranz, R., Schlüter, A., \& Vollan, B. (2018). Morals, money or the master : The adoption of eco-friendly reusable bags. Marine Policy, 96, 270-277. https://doi.org/10.1016/j.marpol.2018.01.029

Thomas, G. O., Poortinga, W., \& Sautkina, E. (2016). The Welsh Single-Use Carrier Bag Charge and behavioural spillover. Journal of Environmental Psychology, 47(2880), 126-135. https://doi.org/10.1016/j.jenvp.2016.05.008

Zhu, Q. (2011). An Appraisal and Analysis of the Law of "Plastic -Bag Ban," 5, 2516-2521. https://doi.org/10.1016/j.egypro.2011.03.432 